\title{
SANSKRIT-INSCRIPTIE TER EERE VAN DEN JAVAANSCHEN VORST ER-LANGA.
}

\author{
DOOR
}

Dr. H. KERN.

In het Museum van oudheden te Calcutta vindt men twee groote steenopschriften afkomstig van Java.' Wanneer en hoe die monumenten naar de hoofdstad van Britsch-Indië overgebracht zijn, schïnt niet geboekt te wezen, maar het lijdt m. i. geen twijfel, of ze zijn ten tijde van het Engelsch tusschenbestuur onder Raffles naar Calcutta verscheept. Vermoedelijk heeft Raffles zelf daartoe last gegeven, want omtrent een ander gedenkstuk, den beruchten Minto-steen, die thans in Schotland nabij Hawick bewaard wordt, weten wij uit de beste bron, dat genoemde bewindsman dien ten geschenke zond aan den toenmaligen opper-landroogd van Engelsch Indië, Graaf Minto. »I am very grateful”, schrïft deze laatste in eenen brief, gedagteekend 23 Juni 1813, aan Raffles, »for the great stone from the interior of your island, which you tell me, in your letter of the $5^{\text {th }}$ May, was put on board the Matilda. - I shall be very much tempted to mount the Javan rock upon our Minto Craigs, that it may tell eastern tales of us, long after our heads are under smoother stones". ${ }^{1}$ )

Men kan niet zeggen dat die overbrenging van bedoelde gedenkteekenen der Javaansche oudheid gestrekt heeft ten bate der wetenschap. Integendeel. Had men die overblịfselen eener verdwenen beschaving rustig gelaten waar ze waren, dan zouden ze voor degenen die het meeste belang er in stellen lichter toegankelijk geweest zijn en eerder de aandacht van het geleerd publiek getrokken hebben dan thans het geval is. Natuurlijk heeft Raffles zulks niet voorzien, en het zij verre van mï hem een verwijt te maken van

2) History of Java,-D. II., Appendix CCXXI,

4e Volgr. X. 
hetgeen hij deed, maar toch meen ik dat zijn voorbeeld de verzamelaars van oudheden tot voorzichtigheid moet aansporen. Alle voorwerpen die veiliger te bergen zijn in de zalen van een museum dan elders, omdat ze anders blootgesteld zouden wezen aan de verderfelijke invloeden van het klimaat of aan de vernielzucht en onverschilligheid eener barbaarsche bevolking, schrome men niet van de plaats waar ze gevonden worden weg te voeren, maar waar geen gevaar te voorzien is, late men ze liever waar ze zijjn. Bij wïze van voorzorg, kan men van beelden en opschriften nauwkeurige copiën maken, hetzij lichtbeelden of aftruksels naar gelang van omstandigheden, en verder de afdruksels in gips overbrengen, opdat men altoos een getrouw beeld van 't oorspronkelijke bezitte, indien 't laatste onverhoopt schade mocht lijden.

De twee bovenbedoelde beschreven steenen in 't Museum te Calcutta schijnen daar nimmer een voorwerp van onderzoek te hebben uitgemaakt. Dat laat zich gereedelijk verklaren, als men bedenkt, dat beide monumenten beschreven zijn met Oud-Javaansche letters. Men zal dus niet vermoed hebben, dat de taal van 't eene stuk zuiver Sanskrit was, want had men dit geweten, dan zou men zeker in eene plaats die zooveel beoefenaren van de heilige taal der Indiërs telt, als Calcutta, niet nagelaten hebben van den inhoud van het stuk kennis te nemen. Toen mijn vriend K. F. Holle te Garoet, aan wiens blik niets ontsnapt van hetgeen voor Java's oudheid en geschiedenis van belang is, van het bestaan dier opschriften kennis kreeg, wist hij zich afdruksels van beide stukken te verschaffen; het eene, waarvan hij terstond zag dat het in 't Sanskrit gesteld was, zond hij mij toe, met het verzoek den inhoud bekend te maken. Bij de ontcïfering bleek mï al spoedig, dat het opschrift èn om den persoon die daarin verheerlijkt wordt èn om de vermelding van enkele geschiedkundige feiten hoogstbelangrijk was, zoodat ik besloot den Sanskrit-tekst - voor zooverre die leesbaar was - met eene vertaling uit te geven.

Ik zeide daar » voor zooverre die leesbaar was", omdat de -karakters op veel plaatsen, vooral in het middengedeelte, te onduidelijk zijn, althans voor mij, om er geheele volzinnen van te herstellen. Of diowndesbarbreid 
de omstandigheid dat de steen van aard week is, zoodat de omtrekken der letters tengevolge van afschilfering niet meer te onderscheiden zijn, dan wel of het afdruksel niet met de noodige zorg behandeld is, durf ik niet beslissen. Iets zonderlings is het dat hier en daar tusschen de regels flauwe sporen van letters zichtbaar zijn, zoodat het, oppervlakkig beschouwd, den schïn heeft alsof de steen een palimpsest is. $\mathrm{Nu}$ heb ik wel eens gehoord van koperplaten, die men na min of meer onvolledige uitwissching van eenen ouderen tekst opnieuw beschreven heeft; ook zijn er in Indië voorbeelden dat men op steenen over de oude letters heen, nieuwe gekrabbeld heeft, doch dat men voor een stuk van dien aard als onze inseriptie ter eere van den doorluchtigen Er-langa is, een reeds vroeger beschreven steen zou gebruikt hebben, is moeilijk te verklaren. Ik geloof niet dat het raadzaam is zich hieromtrent in gissingen te verdiepen vórdat men de zekerheid erlangd heeft dat diezelfde sporen van letters op den steen zelven te bespeuren zijn. Als vroeger of later een deskundige het oorspronkelijke nauwlettend onderzoekt, dan zal hij dit punt denkelijk tot klaarheid kunnen brengen, en hịj zal tevens, daarvan ben ik overtuigd, nog veel kunnen onteijferen van de gedeelten die op het afdruksel weinig meer vertoonen dan witte plekken op een zwarten achtergrond.

De afmetingen van de beschreven oppervlakte des steens, zijn, naar het afdruksel te oordeelen, in hoogte: 1,24 meter; in breedte: 0,95 van boven en 0,86 van onderen. Het aantal regels is 37; dat der strofen: 34 . De letterteekens, die eene flinke, geoefende hand verraden, zijn de gewone OudJavaansche, zooals men die op gelijktijdige koperplaten aantreft. De spelling geeft weinig stof tot opmerkingen, zooals men uit de transcriptie zien zal. Alleen wil ik hier vermelden dat ten opzichte der verdubbeling van medeklinkers achter eene $r$ geen volstrekte consequentie in acht wordt genomen; men vindt nu eens kîrti, pûriva e. dgl., dan weder kirtti, pûrwwa. In tegenstelling tot de gewone spelling, op Java gevolgd, wordt de Anuswâra onmiddellịk vóór sisklanken en $h$ niet altijd door den nasalen keelklank vervangen; men vindt siṃha, hamssî, doch ook wañça. Regelmatig wordt de Anuswâra aan 't einde der Wown Woarden of leden eeener 
samenstelling geassimileerd aan eene volgende $y$ of $w$, overeenstig Pâninini 8, 4, 59. De in dit geval vereischte Anunâsikâ ontbreekt; het is mij ten minste niet gelukt dien te ontdekken. Het is echter volstrekt niet onmogelijk dat het teeken dier Anunâsikâ op den steen nog zichtbaar zal wezen, want de copie is over 't algemeen te flaww en te vol spatten en vlekken dan dat ik over 't al of niet aanwezig zijn van zekere fijnere teekens een beslist oordeel durf uitspreken. Eindelijk zij opgemerkt dat het klinkerteeken voor den tweeklank $\hat{a} u$ weinig of niet van dat voor $o$ verschilt. Daar men in geen enkel geval in twijfel kan staan of door den dichter $o$ dan wel $a$ a bedoeld is, behoef ik bij dit punt niet langer stil te staan.

De taal van het gedicht is gewoon Sanskrit. Ook van de prosodie valt niets bijzonders te zeggen. Strofe $1-3$ en 9 zijn in Âryâ-maat; $4,5,8,15,17-19,21,32$ en 34 in Çârdûlawikrîdita ; $6,7,10-13,16,20,22-24$ en 31 in Wasantatilakâ; 14 in Mañjubhâşhịịi ; 25 in Pṛthwî; 26, 27, 29 en 30 in Mâlinî; 33 in Sragdharâ.

Bij de beoordeeling van de niet onverdienstelijke verzen moeten wij in 't oog houden dat de schrijver een lofdicht op Koning Er-langa vervaardigd heeft en niet een kroniek. Vandaar dat hij van 's vorsten roemrïke daden gewag maakt op een wïze die wel geschikt was om bij de tijdgenooten, welke met de feiten bekend waren, de herinnering daaraan te verlevendigen, maar niet voldoet aan de behoeften van een nageslacht, hetwelk van den gevierden Javaanschen alleenheerscher weinig meer dan den naam kent. Eene duidelijke voorstelling van hetgeen Er-langa alzoo verricht heeft, krïgen wịj door het gedicht niet; het verband der gebeurtenissen blïft ons ten eenenmale duister. Met dat al blijft er genoeg over om deze inscriptie hoogstbelangrijk te maken; als bịdrage tot de kennis der oude geschiedenis wordt ze door geene andere oorkonde in waarde overtroffen.

De herinnering aan Er-langa, of Air-Langa, zooals de naam in Oud-Javaansche stukken pleegt gespeld te worden, ')

1) Daar $e$ en $a i$ in onze inscriptie duidelijk onderscheiden worden, moet men aannemea dat het woord dir, Maleisch ayr, toen reeds in de gewone uitspraak

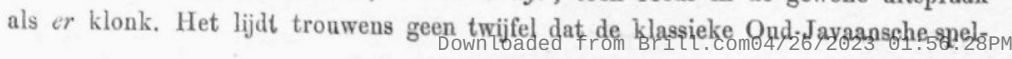


is bij de onwetende Javanen sinds lang uitgewischt. Er is mij ten minste geen enkele Babad bekend, waarin zijn naam vermeld wordt. Bij de Balineezen daarentegen bestaat nog de overlevering dat genoemde vorst in Kediri heerschte en dat onder zijne regeering het eerste bloeitijdperk der Kawiliteratuur valt. $\left.{ }^{1}\right)$ Inderdaad weten wij dat eenige der beroemdste Oud-Javaansche gedichten, de Arjuna-Wiwâha, het Smaradahana, de Sumanasântaka, in zijn tijjd vervaardigd zijn. Dat er grond is om de Oud-Javaansche vertaling van 't Mahâbhârata in dienzelfden tijd te stellen, heb ik elders aangetoond. ${ }^{2}$ ) De eeuw waarin Er-langa leefde was reeds bekend uit een zijner schenkingsbrieven ${ }^{3}$ ) van den jare 945 Çaka (= 1023 A. D.). Deze datum valt na de eerste der in onze inscriptie voorkomende, en vóór de laatste. Er zijn nog andere onuitgegeven oorkonden van Erlanga waarvan de datums met de reeds bekende stroken.

Noch de inscriptie, noch de oorkonden stellen ons in staat om met nauwkeurigheid te bepalen hoever het rijk van Erlanga zich uitstrekte, maar ze bevatten ook niets wat rechtstreeks in strijd zou zijn met de overlevering der Balineezen, dat hij heerscher was van Kediri. Uit het gedicht leeren wij dat hij hoog geëerd werd door den koning van Oost-Java, en dat hij in latere jaren, na eenen tijd van wederwaardigheden, als veroveraar optrad, zijne vijanden in 't Oosten, Zuiden en Westen tuchtigde, en als opperheer van Yawadwîpa troonde in den jare 957 Çaka (1035 A. D.). Eene der onmiddelijke gevolgen van zijne verheffing was de stichting eener kluizenarị, die om haren prachtigen aanleg zóó vermaard werd dat van heinde en verre bezoekers toestroomden om ze te bewonderen. De ligging dier kluizenarij wordt in 't gedicht vermeld; ze lag bij den berg Pûgawat, een Sanskritsche plaatsnaam die »rijk aan betelpalmen" beteekent. Hoogstwaarschijnlijk is Pûgawat slechts eene vertaling

ling in de letterkundige gewrochten en oorkonden een ouder tijdperk der taal vertegenwoordigt, en daaruit volgt dat hef Oud-Javaansch zijn vasten vorm als schrijftaal reeds gekregen had vó́r de oudste ons bekende stukken.

1) R. Friederich, Voorloopig verslag, bl. 8; 18, vg. (Verh. Bat. Gen. XXII).

2) Over de Oud-Javaansche vertaling van 't Mahâbhârata, bl. 6, vg. (Werken der-Kon. Akadèmie van Wetensch. te Amsterdam, 1877).

3) Kawi Oorkonde V (in Cohen Stuarts nitgave) 
van eene oorspronkelijke Javaansche benaming, doch van welke? Dat is niet zoo gemakkelijk uit te maken, en daarom is het dubbel jammer dat men het gedenkteeken van zijne plaats heeft weggerukt om het te begraven in het Museum van eene vreemde stad, waar niemand zich om Javaansche oudbeden bekommert. Het is mij niet gelukt eenen bergnaam op te sporen die als eene vertaling van Pûgawat zou kunnen doorgaan.

Uit hetgeen onze inscriptie vermeldt omtrent de af komst van Er-langa blijkt dat hij van moederszịjde afstamde van Çrî ÎçânaTunga, heerscher van Java. Zijne moeder, Mahendradattâ, was de dochter van koning Çrî Makuța-Waneça-wardhana, wiens moeder de dochter was van Çrị̂ Îçâna-Tunga. Nu komt onder de door Cohen Stuart uitgegeven oorkonden een stuk $^{\text {l) }}$ voor, uitgevaardigd door Çrî Mahârâja Rake Hino Mpu Sindọok, Çrî. Îçâna-Wijaya Dharmottunga Dewa, in het jaar 861 Ç. (939 A. D.), zoodat de vraag oprijst of wij in dezen vorst den betovergrootvader van Er-langa te erkennen hebben. Ten opzichte der tijdrekening bestaat tegen zulk eene veronderstelling geen overwegend bezwaar. Nemen wij eens aan dat genoemde uitvaardiger van bedoelden schenkingsbrief in 861 Ç. reeds grootvader was en dat zijn kleinzoon, Makuța-Wançawardhana, ongeveer terzelfder tijd geboren werd, dan is het heel wel mogelijk dat de dochter van dezen laatsten, de moeder van Er-langa, omstreeks 't jaar 881 het licht der wereld zag. Is zij op twintigjarigen leeftijd moeder geworden van den held der inscriptie, dan moet deze omstreeks 901 geboren zijn. Veel vroeger kan men zijne geboorte niet stellen, want eerst in 957 bereikte hij het toppunt van macht en roem. Het zou dus volstrekt niet onmogelijk wezen dat de Çrî Içâna-Tunga van het gedicht en de Çrî Ị̂̂âna-Wijaya Dharmottunga der oorkonde van 961 één en dezelfde persoon zijn. Men zou zelfs om het vermoeden meer waarschijnlijkkheid bij te zetten, de aandacht kunnen vestigen op twee omstandigheden: de eene, dat de dochter van Çrî Ị̂̂ana, wier naam als heerschende koningin, Çrî Îçâna-Tunga-Wïjayâ nagenoeg gelijkluidend is met dien van den vorst der oorkonde, in 't opschrift

1) K. O. XXII. 
wordt aangeduid - hoewel min of meer bedektelijk - als eene begunstigster van 't Buddhisme; de andere, dat de schenking van Çrî Îçâna-Wijaya Dharmottunga ten behoeve van een Buddhistisch heiligdom geschiedde. Intusschen zijn deze feiten niet voldoende om eene vaste overtuiging te wekken, en het zal dus beter wezen zich van gewaagde gevolgtrekkingen te onthouden, temeer omdat er nog zooveel onuitgegeven opschriften bestaan, die een tal van ongebruikte gegevens, jaartallen en vorstennamen, bevatten.

De lotgevallen van den held worden door den dichter meer aangeduid dan wel geleidelijk verhaald. Er is in het stuk geen gebrek aan beschrijvende verzen, maar die beschrijvingen hebben betrekking op bijzaken, terwijl de hoofdzaken slechts aangestipt worden. Misschien is de dichter met opzet over sommige gebeurtenissen heengegleden, doch het kan kwalijk aan voorzichtigheid, hoe overdreven ook, toegeschreven worden dat hij zoo bijzonder spaarzaam is met de vermelding van plaatsnamen. Eerder mag men vermoeden dat hij het zooveel mogelijk vermeed Javaansche woorden in zij̄n verzen te gebruiken. Den naam Er-langga, die echt Maleisch-Polynesisch is, kon hï niet verzwijgen, maar hij veroorlooft zich toch het woord hier en daar te sanskritiseeren, door 't eerste lid der samenstelling, er, water, te vertalen, zoodat de doorluchtige heerscher door hem ook wel Jalalanga en Nîra-langa genoemd wordt ').

In hoofdzaak vertelt ons de dichter het volgende. Er-langa was de zoon van Udayana en Mahendradattâ. Hij werd met groote onderscheiding behandeld door Çrî-Dharmawan̉ça, vorst van Oostelijk Java, en verwierf zich door een bezoek aan dien vorst niet weinig aanzien. Niet lang daarna evenwel trof hem het ongeluk dat zijne hoofdstad in de asch werd gelegd - vermoedelijk in een oorlog, doch dát wordt er niet bij verteld. Met eenige getrouwen, bedienden en aanzienlijkke

1) Lañga, d. i. slurpen, Nieuw.Jav. longå, wordt door den dichter nergens vertaald. In het Handwoordenboek van Roorda wordt $\eta \underset{n}{\text { gेe }}$ m opgegeven, maar de stamvorm is $\eta$ nirem, zooals o. a. blijkt uit eene plaats in den Kantjil:

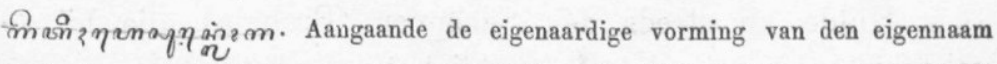
weet ik geen verklaring te geven. In Balineesche HSS. is langa verhaspeld tot lainghya. 
mannen zocht hij een toevlucht in de bosschen, en daar, op den gedenkwaardigen dag van den $13^{\text {den }}$ der maand Mâgha van het jaar 932 Çaka was het, dat hị door zijne getrouwen en de brahmanen, vol vertrouwen, werd gesmeekt, het gansche land in zijne macht te brengen. Van toen af dagteekende zijne zegevierende loopbaan; hij beoorloogde met gunstigen uitslag naburige vorsten; fnuikte in 954 Ç. eene gevreesde vorstin, die afgeschilderd wordt als eene reuzin in kracht, doch niet genoemd; ondernam een tocht naar de zuidergewesten, waar-vandaan hij met buit beladen terugkeerde; wendde zijne wapenen daarna tegen het Westen en versloeg den koning des lands, Wijaya geheeten, op den $13^{\text {den }}$ der maand Bhâdrapada van 't jaar 957 Ç. Een paar maanden later werd Wüjaya door zijne eigene troepen verraderlijk vermoord, en op den laatsten dag van Kârttika van hetzelfde jaar plaatste Er-langa zich op den troon als oppervorst van Java. In de volheid van zijn voorspoed besloot hij tot den aanleg der prachtige kluizenarj op de helling van den berg Pûgawat, wier fraaiheid die van Indra's lusthof evenaarde. Met den wensch dat de koning nog lang leven moge tot beil zijner onderdanen wordt het gedicht besloten.

Ik laat nu de vertaling volgen van den tekst zelven, die hierachter in transcriptie is medegedeeld, voor zooverre ze leesbaar is. Aan de nitgave van een facsimile van het stuk viel niet te denken; daartoe is het afdruksel te gebrekkig, en als bijdrage tot de palaeographie heeft het opschrift geene bijzondere waarde.

\section{VER T A L I N G.}

\section{HEIL!}

1. Hulıe, zij steeds den Schepper (Brahma), die bij de schepping des menschdoms en bij het onderhoud (der wereld)

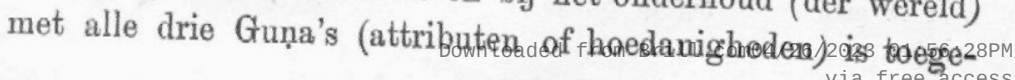


rust, doch bij den ondergang erkend wordt als te zijn Gunaloos $\left.{ }^{1}\right)$.

2. Hulde zij ook hem, die in de wereld bekend is als de Triwikrama (d. i. de Driestappige Wishṇu), voor wien de Heer der goden (Indra), zoo groot door ontelbare heldendaden, zich altijd in vereering buigt.

3. Hulde aan Çiwa, die den grooten Wonderboom (die alle wenschen bevredigt) overtreft, daar hï, hoezeer een sthânu ${ }^{2}$ ) zịjnde, door zijne volmaaktheden in nog hoogere mate de wenschen en behoeften der schepselen bevredigt.

4. Leve ${ }^{3}$ ) Koning Er-langa, die door zịn ongeschonden goeden naam en barmhartigen zin de vrouwen volgt; door het aanhalen van den boog zijne hand een ergen smet aanwrïft, en, hoewel een held in den oorlog, door den rug toe te keeren aan zedeloosheid zich aan vreesachtigheid schuldig makkt, en zoodoende juist door zijne deugden niet aan gebreken ontsnapt.

5. Er was een vorst die de kroon spande onder de hoeders der aarde, en eene groote menigte van koningen overwonnen had; vermaard in alle drie werelden, en in grooten heldenmoed een leeuw gelijk. Onder zijn langdurig bestuur bracht de vergankelịke aarde onmetelijk veel vruchten voort en genoot zij voorspoed. Het was de met luister, roem en macht gezegende beheerscher van Java, Çrî-Ị̂̂ana-Tunga genaamd.

1) D. i. in den staat van rust of in abstracto is Brahma Guna-loos, maar in den staat van werkzaamheid of als concreet wezen gedacht openbaart hij zich in de vormen van licht en zedelijke reinheid; van schemer, of in zedelijke opvatting: gemengd goed en kwaad; en eindelijk, van volslagen duisternis, en geestelijk opgevat: van boosheid en dwaling.

2) Sthânu beteekent "paal" en is tevens een naam van Ciwa. De rhetorische aardigheid ligt tn 't woordje "hoezeer", dat alleen past als de hoorder sthânu oppervlakkig als "paal" opvat. Dergelijke woordspelingen, die een niet geringe mate van wansmaak verraden, zijn de trots en wellnst der latere Indische dichters.

3) Het juiste gebruik van den imperatiefvorm jayatad (eig. zij overwinnaar), die in het zoogenaamd klassieke tijdperk der Sanskritletterkunde zó6 zeldzaam is, dat Prof. Whitney in zijne Sanskrit Grammar $\$ 571$ er geen enkel voorbeeld van weet aan te halen, toont dat de dichter goed de Indische spraakkunst bestudeerd had. Zulks neemt niet weg dat de constructie yas - dadhat in den eersten regel ongrammatisch is, althans in de klassieke taal geheel ongewoon. Het is eckter licht te begrijpen waarom hij het deelwoord gebruikt heeft instede van dadhati, omdat dit laatste niet in de maabopmstraded from Brill.come4/26/2023 01:56:28PM 
6. Diens dochter, liefelijk door de reinheid van haren inborst (akalushamânasawâsaramyâ) en de partij der Buddhisten toegedaan (sugatapakşhasahâ), gelijk aan eene zwaan, die bekoorlijk is door 't verblijf in het reine meer Mânasa (akalushamânasaựasaramyâ) en schoone vleugels heeft (sugatapałąasahâ); (zij) die de blijvende vreugde was van den phenix der koningen (anders: van de vorstelijke mannetjeszwaan), heerschte als koningin onder den naam van Çrî-ÎçânaTunga-Wijayâ.

7. Toen maakte koning Çrî-Lokapala '), een uitstekend vorst, oogverrukkend (in voorkomen) haar tot zijne welbeminde, en (zelf) beroemd om de groote reinheid van zijn gemoed, maakte hij haar, gelïk de (blanke) Melkzee de (zuivere) Mandâkinî, aan zich gelijk in geluk.

8. Uit hem sproot een zoon, uitblinkende in macht en bestemd om de aarde tot sieraad te strekken; die, daar zijn geest steeds gericht was op de bevordering van het welzijn der schepselen, de aarde zegenrïk deed gedịjen, en gelijk de luisterrijke Wishṇu met onvergelijkelijken glans verrezen, onverschrokken kumbha's (potten), (namelijk de) kumbha's (zwellingen aan de slapen) van de olifanten der vijanden, verpletterde; een vorst der vorsten.

9. Deze onvergelïkelijke monarch, bekend onder den naam van Çrî Makuțawaǹçawardhana, een zon in het geslacht van Çrî Îçâna, blonk helder uit in dapperheid.

10. De overschoone dochter van dien vorst, die om de voortreffelijkheid van haar wezen (?) als het ware het rijksgeluk van Java in levenden lijve was, ontving van haren vader den (bij)naam - die ook buiten het eiland populair werd - van Gunapriyadharmapatnî (d. i. echt-gemalin van den Vriend der Deugd).

11. Er was namelijk iemand van uitnemend zuiver bloed, de uit een beroemd vorstengeslacht gesprotene Udayana. Hij was het ${ }^{2}$ ) die de schoone prinses Mahendradattâ plechtig huwde.

12. Uit hem sproot een zeer schoon kind, Er-langa-Dewa

1) Ik denk dat dit hier een eigennaam is, ofschoon men het aan den vorm van 't woord niet zien kan. -

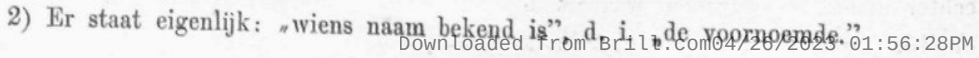


genoemd, gelịk Râma uit Daçaratha (en) diens meerdere door zijne voortreffelijke hoedanigheden; hij muntte uit onder allen in den lande en was innemend in allen deele ${ }^{1}$ ).

13. Toen hij door den heerscher van Oost-Java, zijn aanverwant, die door 't hooren van zijne vele deugden begeerig was hem te zien, eerbiedig uitgenoodigd was geworden op de bruiloft van diens dochter, verbreidde zich de roem van den edelaardigen Er-langa weldra allerwege.

14. Niet lang daarna werd zijne hoofdstad, waar zoo lang (?) eene vrolijkheid heerschte als in Indra's rijk, in de asch gelegd. Vergezeld van eene geringe ruiterwacht ${ }^{2}$ ), van zijne dienstboden, en de voornaamsten des volks begaf hịj zich naar de bosschen.

15. En toen, in het belangrïke jaar 932 na den Çakavorst, den $13^{\text {den }}$ van de lichte helft der maand Mâgha, op eenen Donderdag, kwamen tot den doorluchtigen monarch, Koning Er-lañga, de onderdanen en de voornaamste brahmanen, met innig verlangen, en, eerbiedig gebogen, richtten zij vol vertrouwen de bede tot hem: »Beheersch het land tot aan de uiterste grens!"

16. Wanneer zijne talrijke tegenstanders vernemen hoe die vorst, na gewijd te zijn tot (toekomstig) keizer, door zijne macht de menigte der vijanden overwon, vreezen zij ook nu nog in 't bereik te komen zijner armen, als waren het slangen, en leeren zij, als het ware, eene wankelmoedigheid die hun vroeger vreemd was.

17. Verscheiden vorsten van Java hebben de inkomsten des lands genoten omdat zij smeekelingen werden bij hun tegenstander; uit kracht hunner koninklijke geboorte genoten hun zonen (?) (weelde) op den koningstroon, maar de doorluchtige vorst Erlanga-Dewa, van geslacht een voorganger onder de potentaten, ach, hij heeft alleen een bitteren

1) Kalabhirama beteekent tevens "Door de kunsten (die hij leerde) behagende" en bekoorlijk door zijne kala's d. i. zestiende deelen, van de maan gezegd. De woordspeling abhiramo Ramo gaat in de vertolking natuurlijk te loor; er is niets aan verloren.

2) De lettergreep die ik in de transcriptie oningevuld heb gelaten, vertoont zich als eene onduidelijke $g a$ of $\xi a$, doch dat geeft geen zin. lk vermoed dat er

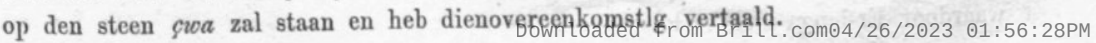


vijand: koude en hitte, aan het lichaam te verdragen ') terwïl hï rondzwerft over de aarde.

18. Op den troon gezeten, met beide voeten op de hoofden der vasallen; dagelijks samensprekingen houdende met zijne aan de overweging der staatszaken zich wijdende ministers, houdt hï vaak zitling, vergezeld van (dienende) vrouwen en omgeven van helden in schitterenden wapendos, en, hetzij een proces (door zijn rechterlïk oordeel) verloren wordt of gewonnen, altoos is zijn helder inzicht even bewonderenswaardig. ${ }^{2}$ ).

19. »Mïn gemaal, die zijne kinderen en mịj, hoewel hịj ons zeer liefhad, in eens heeft achtergelaten, . . . . om te gaan tot de Nymfen des hemels ..... gehoorzaam aan Uw bevel. Gij zijt in de wereld bekend als iemand met een medelijdend hart: hoe kunt Gij dan zoo geheel anders handelen? Waar, o Koning, is Uwe barmhartigheid?" zoo klaagt de vrouw van eenen vijand .....

20. Zekere (vrome) die naar Verlossing streefde, . . . . ; aardsche goederen, dat vuil, zịjn een groote vijand voor het erlangen $\operatorname{van} . .$. Een ander die van den koning gewijde spreuken ontving, welke hem (eenmaal) den hemel zouden openen, werd als het ware zijn leerling.

21. . . . . Waarom tracht gij de kluisters (der zinnelijkheid) niet door werkzaamheid te slaken? Waarom hebt gij er behagen in, daarmede behebt te zijn? Wat doet gij, wiens hooge zin (?) geroemd wordt, met die onstuimige begeerte om de genoegens van 't minnespel te smaken? De

1) De dichter gebruikt opzettelijk driemaal hetzelfde werkwoord $b h u j$, dat in onze taal onmogelijk in de hier voorkomende verbindingen met één woord terng te geven is. De lezing $t a[j j a]$ is zeer onzeker; men zou eer verwachten tushtim, doch er is geen spoor van $u$ onder de duidelijk leesbare $t$

2) De beschrijving van de stiptheid wasrmede Er-langa zijne koninklijke plichten bij de audienties en daarmee gepaard gaande rechtszittingen waarnam, schijut oppervlakkig beschouwd hier misplaatst, daar de dichter toch wel niet zal hebben willen zeggen dat de koning in later tijd minder nauwgezet was. De inhoud van den eersten regel is kwalijk te rijmen met den staat van iemand die, zooals in de vorige strofe gezegd wordt, "over de aarde zwerft." In de volgende strofen is er ook vee. duisters, niet het minst ten gevolge van de leemten in den tekst. Zooveel echter kan men uit die verminkte volzinnen opmaken, dat de dichter daarin een denkbeeld heeft willen geven van de veelzijdige deugden en talenten waardoor Er-langa zich onderscheiddentoaded from Brill.com04/26/2023 01:56:28PM 
roem die loutering bewerkt en .... geeft, blank ... , die (allen) wordt bestendig geëerd."

22. "Indra hebbe het groote woord onder de onsterfelijken en zij stout in daden; Kubera zal uitdeeling van goederen houden onder zijne afhangelingen en de schare van hulpbehoevenden; Yama zal allen door den dood vereenigen"; zoo verkoos het den Schepper (Brahma), de wereldhoeders . . .

23. Er was een koning . . . . ; diens edelaardige zoon, Bhîshmaprabhâwa geheeten . . . . .

24. En een andere, Adhamâpanuda genaamd, die als Râwaṇa in persoon eene overgroote menigte van adhamânga's bezat $^{1}$ ). Dien . . . . . versloeg hïj weldra.

25. En onmiddellijk daarop (versloeg) de naar wereldverovering strevende vorst den koningszoon; hịj verbrande plotseling diens residentie, zoodat er niets van overbleef, en in het jaar 953 van Çaka blakerde de uitstekende monarch diens steden herhaalde malen.

26. Er was ook in het land eene vrouw van geweldige kracht, aan een reuzin gelijk. Onvervaard trok hịj naar haar schier ontoegankelijk gebied. Het was in het ${ }^{2}$ ) jaar 954 van Çaka, dat de koning zich beroemd maakte door dezen prïgs te schieten.

27. Gelijk een vlammende draak (met vurige tongen) om zich heen likkende, verbrandde hij flink ${ }^{3}$ ) die uiterst onbeschaafde zuidelijke streek. Na zeer veel buit behaald en dat aan zijn dienaren geschonken te hebben, nam hij, onder de brahmanen en asceten, den roem alleen voor zich.

28. Door eerzucht bezield, trok hij daarna, in den jare 957 van Çaka ${ }^{4}$ ), op den $13^{\text {den }}$ van de eerste helft der maand

1) D. i. „voeten" en vermoedelijk tevens "voetknechten". Râwana, het veelhoofdige monster, had namelijk, zooals men weet, 20 armen en het schijnt dat de dichter zich daarom gerechtigd .heeft geacht hem ook het meer dan gewone getal voeten toe te kennen. Het bewijs dat met "voet" hier ook "voetknecht" bedoeld is, kan ik niet geven. Anders kan adhamánga ook beteekenen "iemand van een gemeen lichaam", hetgeen ietwat zonderling klinkt.

2) Asmin is een stoplap, daar het hier noch "in dit" noch "in ditzelfde" kan beteekenen.

3) Dakșhinat\$at dient meer om een woordspeling met dakşhindm mogelijk te maken dan om de kracht en fraaiheid der schildering te verhoogen.

4) Lapana is een synoniem van mukha, mond. Daar mukha alleen in den zin van "opening" het getal 9 aanduidt, is het gebruik van Lapana meer dan gewaagd. Maar wat doet een dichter al niet opowhlo magat from Brill.come4/26/2023 01:56:28PM 
Bhâdrapada, op eenen goeden Woensdag, naar het Westen, met een ontelbaar leger van strïdvaardige en krachtige manschappen. Onder de toejuiching der wereld behaalde hij eene volkomen overwinning op den koning, Wijaya geheeten.

29. En in dat jaar 957 van Çaka, op den 8 sten der donkere ${ }^{1}$ ) helft van de maand Kârttika, des Donderdags, werd de koning Wijaya door diens eigen troepen gevangen genomen - dank zij de aanwending van de middelen van staatskunst, zooals die in het leerboek van Wishṇugupta ${ }^{2}$ ) geleerd worden, - en sneefde hij onmiddellịjk daarop.

30. In den jare $957^{3}$ ) na den Çakavorst, op den laatsten van Kârttika, des Donderdags, plaatste de edele Doorluchtige Koning van het eiland Java zegepralend zich op den van juweelen flonkerenden troon, nadat hij zijne voeten gezet had op het hoofd zijner vijanden.

31. Thans, na het Oosten, Zuiden en Westen veroverd en alle vijanden verslagen te hebben, na alleenheerscher geworden te zijn van het gansche land, wordt Zijne Majesteit Er-langga door de koninklijke Fortuin, welke geenen anderen vermag aan te zien, dicht in hare schoone armen gekneld.

32. Nadat hï zijne vijanden door groote geestkracht, door zijne heldendaden, alsook door allerlei middelen van staatskunst, ten onder gebracht had, heeft Zijne Majesteit Er-langa nu hij een groot vorst geworden was, aan de helling van

1) Er zal wel sita voor siti te lezen zijn. In dit geval luidt de vertaling: der lichte helft.

2) Wishnugupta is de Indische Macchiavelli, wiens leerboek orer staatsmanskunst onmisbaar geacht werd voor alle diplomaten. Er is van het Indische stelsel van staatsmanswijsheid veel kwaads te zeggen, maar de lessen daarin vervat worden ook buiten Indië thans nog getrouw in acht genomen.

3) Uit het verband volgt noodzakelijk dat maka, hetwelk volkomen duidelijk te lezen is, "zeven" moet aanduiden. In de woordenboeken wordt een woord maka vermeld, maar niemand weet de beteekenis er van. Zoo maka geen schrijffout is - en het is moeielijk te zien uit welk ander woord voor zeven het hier zou kunnen staan - dan moet maka iets beteekenen wat kan gebezigd worden om gezegd eijfer aan te duiden. Daarvoor komen zooveel begrippen, bijv. berg, muzieknoot, versmaat. paard, ziener, in aanmerking, dat men er moeielijk naar kan raden, welke van die allen bedoeld kan geweest zijn. Even gewaagd zou het wezen te reronderstellen dat de dichter maka nam in den zin van $m a$, en omdat dit een naam eener muzieknoot is, de vrijheid zich veroorloofde maka gelijk te stellen met "muzieknoot" (getalwaarde 
den heerlijken berg Pûgawat eene heilige kluizenarị laten maken, hetzij om zijne macht te toonen of uit onverbrekelijke trouw aan eene gelofte om de goden gunstig te stemmen en te bevredigen.

33. Hoorende van deze weêrgalooze koninklijke kluizenarij, welke niet voor Indra's lusthof behoeft onder te doen, wedjjveren de menschen onophoudelijk om er heen te gaan en staren zij (alles) aan met oogen die van verbazing trillen; zij brengen kransen, enz. als blijken van hun ingenomenheid en hebben den mond vol van den lof van dezen uitnemenden vorst, dien zij als eene Zon onder de fiere (heerschers) achten en om zijnen luister vereerenswaardig noemen als een Manu.

34. Moge de gemeente der burgers op het pad der deugdzamen wandelen! moge de wandel der staatsdienaren gerecht zijn! Mogen de asceten streven naar het heil aller wezens! (En) ten aanzien van den koning zelven is onze bede: „Daar het aan Zijn leven en aan Zijn bestuur des lands te danken is dat deze (allen) in gerechtigheid kunnen gedijen, moge Zijne Majesteit Erlanga-Dewa daarom nog lang leven!" 
TEXT OVERGESCHREVEN IN NÂGARÎ.

\section{॥स्वस्ति॥}

त्रिभिरपि गुणिरुपेतो नृएात्विधाने स्थितो तथा प्रतये स्रगुए इति यः प्रसिद्धस्तम्मे धात्रे नमस्सततम् ॥ (1) स्रगणितविक्रमगुरुणा प्रणाम्यमानस्तुराधिपेन सदा (ग्र)वि यस्त्रिविक्रम इति प्रथितो लोके नमस्तस्मे ॥ (2) य स्थापुरुप्थतितराथ्यथित्सितार्थप्रदो गुणोर्जगताम् कल्पड्रममतनुमधः करोति तस्मे शिवाय नमः ॥ कीर्त्यावणिडतया धिया करुणाया वस्त्रीपरवन्द्ध-

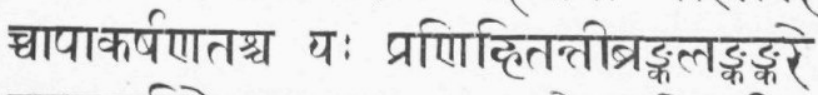
वश्चासचरिते पराझुख्युतया भूरो रो भीरुतां स्वेद्दोषान्भनते गुणोस्स जयतादेर्तड्रनामा नृपः ॥ ग्रासीन्निर्जितभूरिभूधरगणो भूपात्तचूडामाएँ: प्रख्यातो भुवनत्रयेपि महता शौर्येया सिंद्रोपमः येनोर्वो सुचिरन्धृतामितफला लन्मीन्द्धो गतरी सश्रीकीर्तिवत्तान्वितो यवपतिशश्रीशानतुड़ाद्धयः ॥

तस्यात्मनाकल्तुषमानसवासरम्या हंसी यथा सुगतपक्षसह्राभवच्चा

सा राजहंसमुदमेव विवर्धयन्तो श्रोशानतुड़्रवियेति राज राइी ॥ मन्दाकिनीमिव तदात्मसमां समृध्या ज्ञोरार्णावः प्रथितथुहिगुएात्तरात्मा 
तास्चाकरोत्प्रणायिनोन्नयनाभिनन्दी

श्रील्तोकपाल्तनृपतिर्नर नायनागः ॥ (")

तस्मात्प्राहुरूत्प्रभाववि(श)दों भूषणोड़ूतये

भूतानाम्भवभावनोधतधिया क्माम्भावयन्भूतिभि:

शौरिश्चाप्रतिमप्रभाभिर्योो भास्वानिवाम्युध्यत -

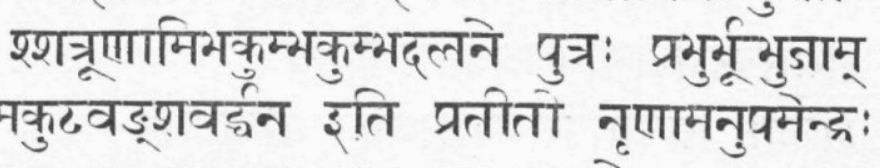

श्रोशानवड़शतवनसतताप भुभ्रम्प्रतावेन ॥ (9)

तस्याधिपस्य हुद्तितातिमनोजूदूपा

मूर्तेव भाव(?)गुएतो यवराजलन्त्मी:

द्वीपात्तरेपि सुभगेन बभव पित्रा

नाम्ना कृता वत्तु गुणाप्रियधर्म्मवन्नो ॥ (10)

ग्रासीदसावयि विशिष्टविभुछजन्मा

राजान्वयाहुद्वनः प्रथितात्प्रजातः

तां श्रीमतीव्विधिवदव महेन्द्रदत्ता-

व्यक्ताद्बयो नृवसुतामुपयच्छे स्म ॥

श्रेष्ठः प्रजासु सकतासु कताभिरामो

रामो बथा दशरथात्स्वगुणोर्गरीया-

न्सम्भावितोन्नतगतिर्मद्हसा मुनीन्द्रै-

रेस्तड़द्व इति दिव्यसुतस्ततोभूत् "

श्रीधर्म्मवंश इति पूर्वयवाधियेन

सम्बन्धिना गुएागएाश्रवणात्मुकेन

ग्राद्यय सादरमसो स्वसुताविवाह-

न्द्राक सर्वथा प्रयितकोर्तिरिभून्महात्मा ॥

स्रथ भस्मसाद्ववदाशु तत्पुर -

म्युरूल्लतराष्ट्रमिव मुयुतं चिरें (?)

तत्विना - लेन वत्तु किड़रैर्विशा (1. वशा) 


\section{स नरोत्तमेरुपहितो वनान्यगात् ॥ (14)} शाकेन्द्रेय - लोचनाग्निवदने यति महावत्सरे माघे मासि सितत्रयोदशतियो वारे शशिन्युत्मुक्के: ग्रागत्य प्रएतिर्जनेर्द्धिजवरेस्साश्वासमभ्यर्थित-

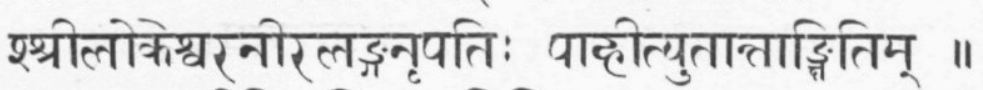

सम्राज्यदोक्तितमिनन्नृपतिन्निशम्य

शक्या जितारिनिकरन्निवहो रिपूएाम्

ग्रयापि तहुजभुजड़्तत्तस्व बिभ्य-

दम्यस्थतीव (चप)लवनभूतपूर्व्यम् ॥

भूयांसो यवभूभुजो बुभुजिरे पृथ्वोक्तिपन्तेर्थिनस्सामर्थ्यान्नृपनन्मनो नु(?)बुभुजस्त - नरेन्द्रासने तितं श्रोजत्तलड़े वन वत्तिर्वश्याधि(नाया) ग्रएणीरी ग्रड़्रे स भुनत्ति केवत्तमरिन्द्रन्दम्ब्रमन्भूतत्ते। भूभून्मस्तक(स)त्तादगुगत्तस्सिंहासने संस्थितो मन्नात्तोचनतत्परेरहरहस्मम्भाषितो मत्तिभिः भास्वहिर्त्त्तनान्वितो निविशते वीरेः परोतो भृशं ज्योतिस्तस्व पराजये विजयवच्चित्रीयते सन्ततम् ॥ पुत्रान्मामतिवत्सत्रोपि सहसा त्यक्का मदोयः पतिस्वर्गस्त्रोगननो —... - ग्राज्ञाविधियस्तव ख्यातस्वम्भुवने दयातुद्धद्धयत्तन्या प्रवृत्तिः कथम् हा राजन का कृपित्यर्वानितया - . या लघ्यते ॥ कश्चिन्मुमुन्तु

- वापये धनमत्तानि महानरातिः। कश्चित्रिविष्टपमुखान्नृवरस्य मत्त्रान्सम्प्राघ्य शिष्य इव तेन कृतस्स ग्रासीत् ॥ तुड़ा - भुवनत्रयस्व महृ -...... किं बन्धा न चिकीर्षया क्न - किं तयुत्ते रस: 